Working

Paper

Department

of Economics

$\mathrm{Ca}^{\prime}$ Foscari University of

Venice

Antonio Russo

Jan van der Borg

New culture-oriented

economic development

trajectories: the case study

of four Dutch cities 


\title{
New culture-oriented economic development trajectories: the case study of four Dutch cities
}

\author{
Antonio Russo \\ University Rovira i Virgili, Tarragona \\ Jan van der Borg \\ University of Venice
}

\begin{abstract}
Culture is a key ingredient of post-industrial, information-intensive economic activity. Cultureoriented economic development (COED) is emerging as a dominant paradigm, integrating the symbolic and creative elements into any aspect of the urban economy, pursuing distinction, innovativeness, and a higher level of interaction between localised individual and collective knowledge and globalising markets.

This article presents a dynamic analysis of the effects of culture on the economic development trajectories of European cities. It may contribute to shed more light on the relevance of cultural industries for spatial development, addressing issues such as: cultural endowment, identity and urban competitiveness; dispersed vs. concentration; cultural participation and social inclusion.

The analysis uses data collected within the ESPON project 1.3.3 and other information of qualitative and quantitative nature collected by EURICUR in occasion of a study of a sample of European cities. In this paper we present the investigation conducted in the three largest Dutch cities, Amsterdam, Rotterdam and the Hague, which are part of the city-region of the Randstand, and the fifth largest Dutch city, Eindhoven, one the most important economic and educational centres in the Netherlands.
\end{abstract}

\section{Keywords}

Cultural industry, urban economy, creativity, sustainable development, The Netherlands

\section{JEL Codes}

R11, Z10

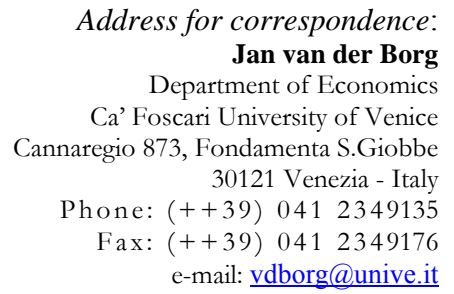

This Working Paper is published under the auspices of the Department of Economics of the Ca' Foscari University of Venice. Opinions expressed herein are those of the authors and not those of the Department. The Working Paper series is designed to divulge preliminary or incomplete work, circulated to favour discussion and comments. Citation of this paper should consider its provisional character.

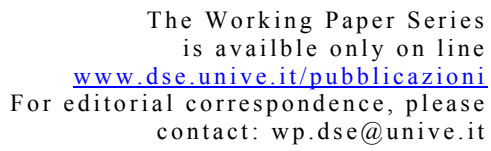

The Working Paper Series

is availble only on line www.dse.unive.it/pubblicazion

For editorial correspondence, please

contact:wp.dse@unive.it

Department of Economics

$\mathrm{Ca}$ 'Foscari University of Venice

Cannaregio 873, Fondamenta San Giobbe

30121 Venice Italy

Fax: ++390412349210 


\section{THEORETICAL BACKGROUND}

\section{The creative economy of cities}

Cities spend more and more in cultural programmes and large infrastructure projects, seeking competitive and sustainable growth: urban landmarks influencing the image and the attractiveness of the city for private investments, but also platforms for the "new creative class" and stimuli to social integration through self-reflection and cultural inclusion. However, there is uncertainty about the returns of such investments. Moreover, seed-funding creativity and cultural dynamism is a complex issue, as traditional institutions and policy approaches are hardly able to come to terms with fuzzy, anarchist social structures.

Today we dispose of a substantial body of literature on the relationship between culture and the city. The conceptualisation of culture as "system of social norms" informs the web of strategic relations which comes as part and parcel of modern forms of organisation of the economy. Florida (2000) argues that in the global economy the social skills of the members of the "creative class" make the strength of the local milieu. Culture also restructures the governance of local growth processes: according to Landry (2001), the governance of a highly dynamic, complex, flexible, and creative society also has to have creative and "lateral" qualities. Finally, Scott (2001) shifts the discussion to culture as an urban "product", or a set of industries that find their natural environment in cities, occupying a central role in regeneration processes, and generating value by feeding global 
functions dependent on image creation and valuation (tourism, infotainment, media, etc.).

The main result from this debate is that cities are key places for the encounter between culture and economic development. However, little progress has been made in passing from abstract reflection to know-how that should orient the action of policy makers, both at local and European level. One main reason for this is the difficulty of defining and delimiting culture, given the complexity of the cultural production and consumption processes, and the heterogeneity of the players involved. In short, the European policy agenda is not yet ready to meet the challenges from a "stealth" area of urban development. This paper may give a contribution in this direction, exploring the implications of the new COED paradigm in terms of opportunities and threats for urban development, and integrating theoretical knowledge with best practices in the field of urban economic planning.

Cities can be described as dynamic systems, which flourish, stagnate and decline as a result of the interaction of the main actors in the urban arena: households, firms, and the government (Van den Berg 1987). Presently, we face a stage of urban development in which city centres are becoming attractive again as business and living locations for highskilled workers (Ohmae, 1995). This change is due to a fundamental shift in the economic realm: the increase in importance of the production of knowledge-intensive services for firms and citizens. Instead of diminishing the reasons for concentration and urbanity, knowledge-intensive businesses derive advantages from mutual proximity and close contact with their customer markets. Producing "intangibles" uses little space, which can be done in inner city locations. This has 
led to the redevelopment of city centres as the main business districts and meeting-places of the new economy, but has also pushed to new extremes the competition between cities to attract investment and economic activities.

In this context, activities of culture and leisure - and the development of dedicated spaces and infrastructure - are major strongholds of urban competitiveness, because they reflect local idiosyncrasies which make any place different from another, and because they contribute dramatically to the transformation of a city from a production to a consumption space with high symbolic value. Despite its global articulation, culture - owing to its highly contextual and inherently unique nature - is indeed a factor of distinction for cities - even conventional cultural products like orchestra performances or museums reflect the typical traits of its host community, through their choice of repertoire and their communication style - and cities are badly in need both of distinction, and of catalysts for regeneration.

Thus, presently the cultural endowment of cities is a building block of their global positioning, and an element of the "image" that governments and business communities utilise to attract resources, people, and capital. Cities can indeed project an allure of modernity and dynamism by investing in new cultural infrastructure and create distinction through grand projects. "Flagship museums" like the MACBA in Barcelona, the Centre Pompidou or the Kunsthal in Rotterdam, as well as other stylish new pieces of cultural infrastructure (the Finlandia Hall in Helsinki, the new project of a glass bridge on the Grand Canal in Venice) have the potential to bring in a rupture in the urban environment, be "surprising", hence 
remembered, and support area renewal projects through the "status" that they provide to them.

Cultural industries also fit perfectly the requirements of the knowledge economy. On one hand, they are highly transversal to many other urban functions. At the fringes of art and culture, there is a whole series of economic activities, the socalled creative industries, in which productivity is linked to the generation of new symbolic content and its integration into commodities. It should also be remembered that culture is a major driver for urban tourism.

On the other hand, cultural industries have important social connotations. Cultural jobs are irregular and flexible, so that cultural employment is an "anti-cyclical" factor in periods of industrial decline and transition, and a vehicle for social mobility in periods of revitalisation and expansion. For these reasons, European cities value cultural employment and agree that there is growth potential in the cultural industries. The demand for cultural goods and services is likely to rise on account of social and economic trends, like the growing welfare and the changes in the lifestyle of retired people, the growing proportion of household income that is spent in culture and leisure, and the increasingly diversifies models of participation in cultural life. It should be added that the observed correlation between the supply of culture and the degree of urbanisation is reinforced by the merging urbanisation trends (European Commission, 1998).

In short, culture can be seen as a driver for a new stage of development of cities based on quality of life, conviviality, creativity, at the same time guaranteeing some balance to such development. Hence the importance for cities to invest in 
culture: heritage management and preservation, art production, events and infrastructure, jobs and creative education.

\section{Impacts of culture and long-term competitive factors}

The European Commission has identified culture and the various sectors of the cultural industry as a major economic and social force in Europe. Employment in the culture and crafts sector is estimated to account for $2 \%$ of overall employment in the European Union in 1999; in 2005 the percentage of cultural occupations calculated within the ESPON project $1.3 .3^{1}$ is estimated at $4.69 \%$ when a large number of creative sectors are considered.

The growth of cultural employment has been strong in the past decade, exceeding average employment-growth figures (Spain $+24 \%$ in the period $1987-1994$, France $+37 \%$ in $1982-1990$, UK $+34 \%$ in 1981-1991, and Germany $+23 \%$ in $1980-1994)^{2}$, to decelerate only slightly in the present decade. A report commissioned by the European Commission - DG Employment and Social Affairs (MKW GmbH, 2001) estimates in 3.8\% the annual average growth rate of employment in Recreational, Cultural and Sporting Activities (NACE code 92) in the 19951999 period in EU15, with Italy, Finland, Portugal and Germany being at the top, and the UK, France, and Austria at the lower end, while Publishing, Printing and Reproduction of Recorded Media (NACE code 22) went actually down $0.1 \%$ in the same period. A study of the cultural occupations (including persons employed in non-cultural sectors) fixes at $4.8 \%$ the

\footnotetext{
${ }^{1}$ See Final Report of ESPON 1.3.3 on the website http://www.espon.eu/mmp/online/website/content/projects/259/657/index_EN.html ${ }^{2}$ Source: European Commission (1998) Culture, the Cultural Industries and Employment, Commission Staff Working Paper.
} 
annual growth rates, with Finland and Sweden at the top of the ranking.

Yet rather than at a macro level, the most important impacts of culture can be appreciated at city level. Culture is eminently a city industry, and more generally an urban phenomenon. Through ages, and in particular since the end of the middleages, the most important works of art, the most influential circles of creative thinking, the best schools and universities, and the flourishing of cultural trends and languages, have been closely associated with cities, their power, and their economic strength. It is thus not surprising that as of today, the cultural heritage of most nations - especially in Europe - is concentrated in cities, and that most starting artists or organisations would look for an urban location. The crossanalysis of ESPON 1.3.3 data and regional settlement types developed in ESPON $3.1^{3}$ confirms the intuition that cultural density is higher the more polarised the settlement structures and the higher the population density in a NUTS III region.

Cultural activities also contribute to define the "boundaries" of development from the spatial/functional point of view, favouring the maintenance of the conditions that are needed to keep the development potential in place. Cultural projects affects the spatial organisation of the city, easing the tourist pressure from congested historical centres and providing regeneration opportunities to peripheral districts (La Villette in Paris, the Gasometer in Vienna, the Forum 2004 in Barcelona); or alternatively, re-focalising attention and investment towards dilapidated central neighbourhoods (the Centre Pompidou in Paris, Schowburgplein in Rotterdam, MACBA in Barcelona). Through the promotion of the local heritage and the

\footnotetext{
${ }^{3}$ See footnote 2 .
} 
conservation of the cultural capital, the sense of place and identity can be maintained and nurtured, generating attractiveness. Finally, cultural activities may ultimately contribute to a more cohesive and balanced society, granting a community the possibility to discover their own and other cultures and histories, and providing access and opportunities of personal development to disadvantaged groups.

To sum up, three "impact areas" of culture on the local economic environment can be identified:

o direct economic impacts from employment and value generation in the cultural industries and indirect expenditure effect, which are so much larger the more "embedded" in the local are cultural professions

o induced effects of cultural activities on the quality of a place, among which the tourist attractiveness, which leverages additional visitor expenditure, but also the location amenities for companies

o "creative inputs" accruing to the local networks of production (both to products and processes of production, or organisational models). These are "cultivated" in a lively and stimulating cultural environment where a creative class develops, attracted by tolerance, openness, educational and social opportunities.

While these effects are thoroughly studied, we focus on the dynamic relation that there exists between them. We then envisage a Culture-Oriented Economic Development (COED) 
model for the city, based on the mutual influence between inner cultural production sector dynamics, economic impacts, and socio-environmental impacts. By ultimately affecting the social mix of the city, its physical / spatial structure and its very cultural identity or capacity for self-reflection, COED is an inherently dynamic process. Indeed, successes and failures in cultural development are likely to change the "initial positions" from which development impulses sprung. In fact, property-led, corporation-driven development strategies could lead to the diminishment of those urban idiosyncrasies which were the original reason to re-concentrate, levelling on the "social" side the economic benefits that may be pursued from agglomeration. This process of gentrification does not need to be the end point for cultural vitality in a city, however; the "cultural arena" may simply shift where new favourable conditions are present. However, the capacity to sustain such "seek and destroy" model of culture-led development could be limited by the availability of adequate spaces in the city. These should remain sufficiently cheap, with a favourable structure of property rights, and not too eccentric with respect to consumption areas in the city. It is thus a challenge for urban policy to keep the process of development in balance, achieving "sustainable" urban development.

\section{A policy model to accompany the development of COED}

The three levels of development of culture - as industry organised in dense economic clusters of production and consumption of symbolic goods, as input that is likely generate change and innovation in other economic sectors and in the urban economy at large, and as structuring element of urban growth - are likely to be highly interrelated, and so are their impacts. Policy should recognise these interrelations and the 
opportunities and threats that present at any stage of the COED, steering it into the desired direction and preventing possible unsustainable outcomes.

- In a first stage, which may be called exploration, an embryonic cultural industry tries to "flourish", reaching sufficient mass and structure to be endogenously sustainable, and policy must accompany this effort. It can do that through a sound policy of cluster development, grounded in an explicit "planning philosophy" which acknowledges culture as a pillar of local socio-economic development.

- In a second stage, called enhancement, cities (or neighbourhoods within larger metropolitan areas) that do manage to develop one or a number of cultural clusters become attractive for new user groups, through culturedriven urban regeneration processes and the formation of new social networks and values. Preconditions are the permeability of cultural clusters in the urban fabric, the existence of a social strategy in the rehabilitation of buildings and public space, and a communication style of the local government focusing on tolerance, diversity, "coolness".

- In a third stage, called diffusion, creative cities "a la Florida" develop in the best conditions to "infect" traditional and innovative economic sectors, contributing dynamism and innovativeness. Value chains get richer by coming in contact with "symbolic value generators" (designers, advertisers, playwright, video-artists, event organisers, etc.). In this stage, the maximum osmosis between traditional and non traditional economic sectors 
needs to be ensured, and platforms need to be established where information are exchanged and human resource mobility is facilitated. The development of campus facilities, incubators, science parks, and other "infectious" locations will also be fundamental.

- In the fourth stage, tagged as stabilization, the development of a creative economy generates a pressure on the real estate market, producing gentrification and social change, and - possibly - conflict between urban economic strategies and the ambitions of the local society. For instance, "flagship" investments may lead to a global convergence in cityscapes (same icons everywhere, often designed by the same architects with the same materials in any place), depleting rather than enriching urban uniqueness (Eisinger, 2000, Richards and Wilson 2005). Negotiated, inclusive planning models are then required to keep the creative potential in place and presence the attractiveness and convenience of the city for culture.

Four case studies are used in the next section to test this policy model empirically, and derive suggestions from real-world examples of its application.

\section{Case study area: background facts}

The Netherlands are a country where culture has been taken very seriously as a factor of social and economic development. National cultural policy is rooted on the assumption that the State should distance itself from value judgements on art and science. Artistic development has, therefore, been much the result of the activity of private citizens and a large number of foundations, though advisory bodies are present at the national 
and local level, such as the Culture Council (Raad voor Cultuur), the Amsterdam Arts Council, the Rotterdam Arts Foundation, and several others.

In the $1970 \mathrm{~s}$, cultural policy became a part of the government's welfare policy, stressing its social role and the importance of cultural participation. After the economic stagnation of the early $1980 \mathrm{~s}$, the reliance of cultural institutions on public funding was put into question and the possibility to tap from external resources was granted, accompanying a reduction in subsidies. The government was to steer this process preparing a Cultural Policy Plan every four years. The 1990s saw a new change, as the government began to offer financial incentives, instead of providing across-the-board funding, encouraging cultural institutions to become more self-reliant and marketoriented. This new approach involved a redefinition of the "societal context" within which cultural institutions operate.

In the same period, there has been a strong growth in interest for culture a matter for local policy. Especially the largest cities of the Netherlands have turned decidedly to culture, in part to reconstruct an "urban model" which was in crisis under the pull of de-industrialisation and strong immigration, and in part to develop urban images and brands which could accelerate the process of transition to a post-industrial, postfordist economy. This focus has been especially strong in Amsterdam and Rotterdam, cities at the forefront of cultural innovation, which have pointed on the "democratisation" of the access to culture and on the multicultural discourse as a social strategy. 
Fig. 1 - Number of jobs in the cultural industries per municipality in the Netherlands, year 2002. Source: elaboration Spatial Planning Bureau of the Netherlands on LISA data (Raspe and Segeren 2004).

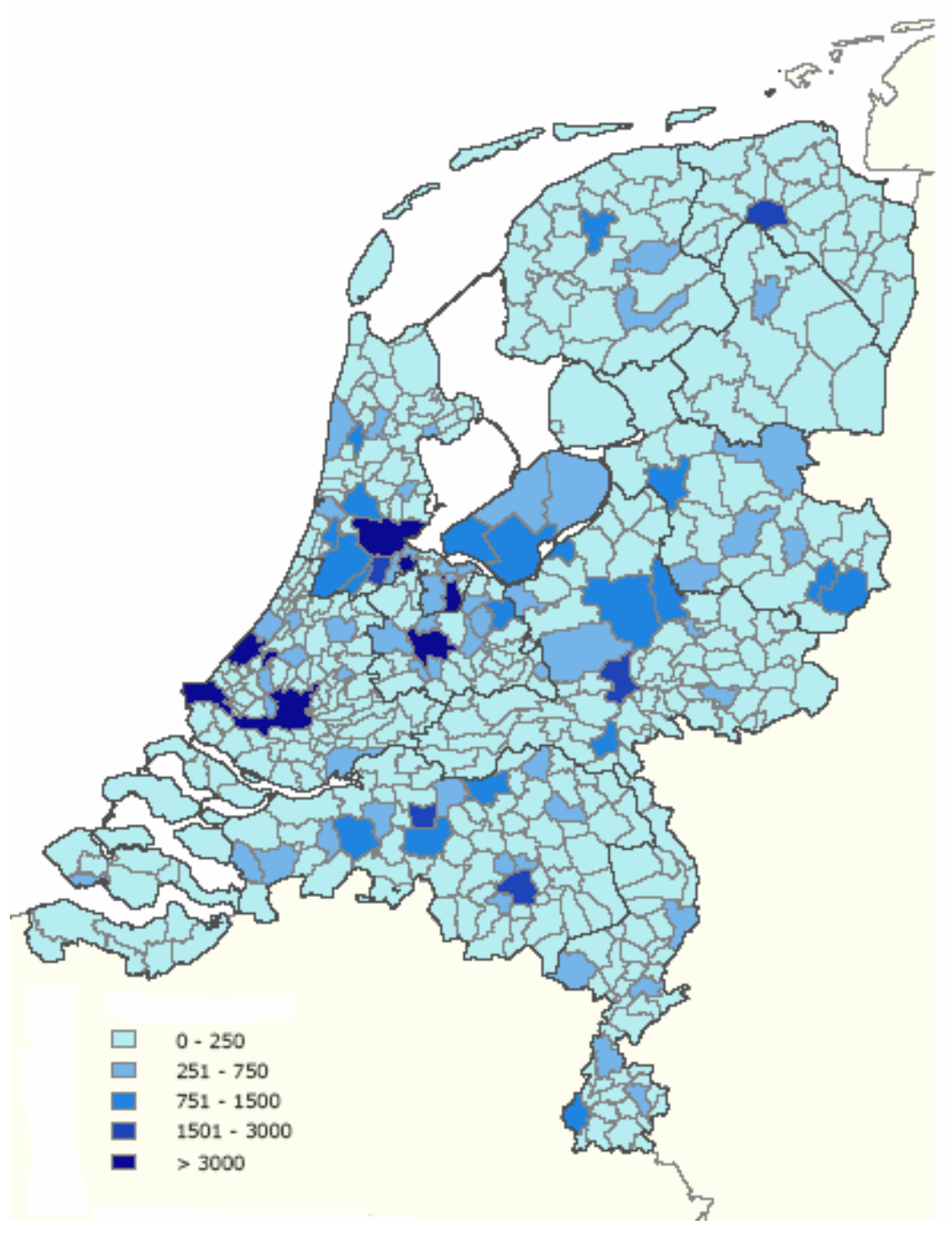

As a result of the emphasis on the "accountability" of the cultural sector, State and local government are very active in monitoring the development and performance of cultural enterprises (see Fig. 1). This is also very important for national and regional planning, as culture is typically seen as an urbanisation factor which could be used to reduce regional unbalances or to spur the growth of lagging cities. Indeed, the 
first three largest cities of the Netherlands as well as Eindhoven, in the south of the country, are all using their cultural spearheads and capacities to varying degrees in order to excel as economic locations and to reduce social problems.

\section{COMPARATIVE ANALYSIS}

\section{Main facts and figure on case study cities}

Table I illustrates the main structural facts about the four cities. They vary in size (metropolitan areas) from 600,000 inhabitants to more than 1.3 million. With the exception of Rotterdam, they are all going through a stage of "reurbanisation", which supposedly puts culture and leisure under the spotlight, the more so in cities where unemployment rates are high, especially if compared to the national figure, like in Amsterdam and Rotterdam. Their population mix is very diverse. Social diversity is also enhanced by student populations, which are large compared to the city size in Rotterdam and Eindhoven. The Hague is the only city in this set without a university of its own, but has two large universities (Leiden and Delft) at very close distance. Finally, these cities tend to be rather attractive to international and domestic visitors; Amsterdam is a real "tourism star" with more than six million visitors a year, while Rotterdam and The Hague serve important regional tourist markets, and Eindhoven is a gateway to an attractive tourist region. 
Tab. I - Main information on case study cities (year 2003-2004)

\begin{tabular}{|c|c|c|c|c|c|}
\hline & $\begin{array}{l}\text { City size } \\
(1,000)\end{array}$ & Pop. Growth & $\begin{array}{l}\text { Unemployment } \\
\text { rate }\end{array}$ & $\begin{array}{l}\text { N. foreigners } \\
\text { / N. HE } \\
\text { students }\end{array}$ & N. of visitors \\
\hline & $\begin{array}{l}\text { (city / metro } \\
\text { area / national } \\
\text { rank) }\end{array}$ & $\begin{array}{l}\text { (city / metro } \\
\text { area) }\end{array}$ & $\begin{array}{l}\text { (abs.; in } \\
\text { national terms) }\end{array}$ & $\begin{array}{l}\text { (share of pop. } / \\
1,000 \text { ) }\end{array}$ & $\begin{array}{l}\text { (overnight stays } \\
\text { by foreigners / } \\
\text { domestic) }\end{array}$ \\
\hline AMSTERDAM & $\begin{array}{l}739 / 1,184 / 1 \\
\text { (nat. capital) }\end{array}$ & $++/+$ & $8 \% /+$ & $\begin{array}{l}32 \% \text { with } \\
\text { ethnic } \\
\text { background } \\
(50 \% \text { of }<19 \\
\text { y-o. }) / 66 \\
\end{array}$ & $\begin{array}{l}6 \mathrm{Mo} / 0.44 \\
\text { Mo }(2003)\end{array}$ \\
\hline EINDHOVEN & $208 / 605 / 5$ & $+1+$ & $7 \%(2004) /=$ & $6,8 \% / 18$ & $\begin{array}{l}6,4 \text { Mo / } 1,4 \\
\text { Mo (region } \\
\text { Noord- } \\
\text { Brabant) }\end{array}$ \\
\hline ROTTERDAM & $599 / 1,362 / 2$ & $-1-$ & $\begin{array}{l}10.6 \%(2004) / \\
++\end{array}$ & $\begin{array}{l}>50 \% \text { "non } \\
\text { white", } 43 \% \\
\text { foreigners / } 50\end{array}$ & $\begin{array}{l}250,000 / \\
435,000\end{array}$ \\
\hline THE HAGUE & $469 / 768 / 3$ & $\begin{array}{l}++(\text { until } \\
2010)\end{array}$ & $\begin{array}{l}6.3 \%(2004) / \\
=\end{array}$ & $\begin{array}{l}<50 \% \text { non } \\
\text { Dutch origin / } \\
1,8\end{array}$ & $\begin{array}{l}261,000 / \\
274,000 \\
(2002)\end{array}$ \\
\hline
\end{tabular}

\section{Cultural highlights}

Table II illustrates the diversity of the sample of cities as far as their cultural highlights are concerned. Each city considered in this sample has something to offer, even though their level of ambition and the "catch" of culture are clearly limited by the dimension and positioning.

Almost all the cities in this study possess an impressive stock of cultural heritage, in part visible in monuments, religious building and historical city grids, in part made of intangible, atmosphere-related elements, which are also a legacy of their political and economic history. Thus, Amsterdam, and Rotterdam, cities which were forged in close relation with the sea and the maritime economy, host an impressive civil architecture reminding of past and present commercial and productive functions, and are relatively open to new cultures 
and innovative social activities. The Hague, the seat of government, has a stately heritage and hosts important art collections. Eindhoven, whose history is closely knit with industrialisation and the working class movement, has a dynamic, young popular culture and a valuable industrial heritage as icons. Cultural activity is boosted by the presence of first-class infrastructure like the Concertgebouw and the Rijksmuseum of Amsterdam or the Mauritshuis in The Hague. Rotterdam caught up to an enviable position, endowing themselves with impressive new facilities in recent years, like the Schouwburg and the Kunsthal. The other cities have regional-oriented facilities which in some cases have risen to national importance thanks to clever programming and marketing (the Municipal Museum of The Hague, the Van Abbe Museum and the Effenaar podium in Eindhoven).

Tab. II - Cultural highlights

\begin{tabular}{|c|c|c|c|}
\hline & Main attractions & Main cultural events & $\begin{array}{c}\text { Main strengths / } \\
\text { weaknesses in city } \\
\text { “cultware" }\end{array}$ \\
\hline & $\begin{array}{c}\text { (city / metro area / national } \\
\text { rank) }\end{array}$ & & (city / metro area) \\
\hline AMSTERDAM & $\begin{array}{l}\text { National museums (Rijks, } \\
\text { Van Gogh), Municipal } \\
\text { museums (Stedelijk), } \\
\text { heritage and historical } \\
\text { sites (Anna Frank house), } \\
\text { historical architecture and } \\
\text { canals, diamonds' craft, } \\
\text { performing arts venues } \\
\text { (Muziekheater, Nationale } \\
\text { Ballet, Stadschowburg, } \\
\text { Toneelgroep, } \\
\text { Concertgebouw) and } \\
\text { companies (le Carré, De } \\
\text { Kleine Comedie, Cosmic } \\
\text { Theatre, Felix Meritis, } \\
\text { Concertgebouw } \\
\text { Orchestra), pop music and }\end{array}$ & $\begin{array}{l}\text { Kwakoe Summer festival, } \\
\text { Floriade, Art markets in } \\
\text { the Spui, Gay Parade, } \\
\text { International } \\
\text { Documentary Film } \\
\text { Festival Amsterdam }\end{array}$ & $\begin{array}{l}\text { STRENGTHS: Liberalism, } \\
\text { tolerance, low access } \\
\text { barriers to culture, } \\
\text { experimentalism in art } \\
\text { forms, grassroots art and } \\
\text { culture } \\
\text { WEAKNESSES: } \\
\text { gentrification of city } \\
\text { centre, tourist } \\
\text { commodification of } \\
\text { culture, conflict between } \\
\text { locals and visitors for } \\
\text { access to culture }\end{array}$ \\
\hline
\end{tabular}




\begin{tabular}{|c|c|c|c|}
\hline & $\begin{array}{l}\text { dance, alternative } \\
\text { lifestyles }\end{array}$ & & \\
\hline EINDHOVEN & $\begin{array}{l}\text { Museums and collections } \\
\text { (Van Abbe), performing } \\
\text { arts and podia (Fritz } \\
\text { Philips music hall, } \\
\text { Standschowburg, Plaza } \\
\text { Futura), Evoluon, pop } \\
\text { music scene and podia } \\
\text { (Effenaar); industrial } \\
\text { heritage (De Witte Dame) }\end{array}$ & $\begin{array}{l}\text { Ice Sculpture Festival; } \\
\text { Virus Festival; Design } \\
\text { Week }\end{array}$ & $\begin{array}{l}\text { STRENGTHS: } \\
\text { Technological education } \\
\text { and the large student } \\
\text { community, industrial } \\
\text { history and legacy, } \\
\text { experimentalism in art } \\
\text { forms, compact and cosy } \\
\text { city centre, "campus city" } \\
\text { WEAKNESSES: } \\
\text { unfocused image, small } \\
\text { mass and peripherally in } \\
\text { Dutch urban system, lack } \\
\text { of animation, lack of } \\
\text { blockbuster attractions } \\
\text { and events }\end{array}$ \\
\hline ROTTERDAM & $\begin{array}{l}\text { Modern architecture, } \\
\text { maritime heritage, } \\
\text { national and municipal } \\
\text { museums (Boymans), } \\
\text { museumpark with } \\
\text { Kunsthal, cultural } \\
\text { galleries quarter in Witte- } \\
\text { de-withstraat, cultural } \\
\text { incubators in regenerated } \\
\text { areas (Van Nelle, } \\
\text { Lloydsqwartier), } \\
\text { performing arts (De } \\
\text { Doelen, Schowburg, } \\
\text { Zuidtheater), pop music } \\
\text { and club culture, ethnic } \\
\text { art, urban culture, } \\
\text { multicultural lifestyle, } \\
\text { sport events, higher } \\
\text { education }\end{array}$ & $\begin{array}{l}\text { European Cultural Capital } \\
\text { Event in 2001, Rotterdam } \\
\text { Filmfestival, Caribbean } \\
\text { Carnival, Dance parade, } \\
\text { Gergiev Festival, Jazz } \\
\text { festival, Dunya } \\
\text { multiethnic festival, } \\
\text { Harbour days maritime } \\
\text { festival }\end{array}$ & $\begin{array}{l}\text { STRENGTHS: Openness } \\
\text { to traditional art forms, } \\
\text { modern cityscapes and } \\
\text { innovative use of urban } \\
\text { public space, large } \\
\text { multiethnic community } \\
\text { WEAKNESSES: lack of } \\
\text { image of cultural } \\
\text { destination, conflictive } \\
\text { ethnic culture, small } \\
\text { cultural networks, lack of } \\
\text { blockbuster attractions }\end{array}$ \\
\hline THE HAGUE & $\begin{array}{l}\text { Medieval city centre and } \\
\text { palaces; museums and } \\
\text { collections (Mauritshuis; } \\
\text { municipal museum); pop } \\
\text { music and venues; } \\
\text { Spuiplein complex } \\
\text { (theatres and movie } \\
\text { house) }\end{array}$ & $\begin{array}{l}\text { North Sea Jazz festival } \\
\text { and other open-air music } \\
\text { events (Parkpop); open- } \\
\text { air sculpture exhibitions }\end{array}$ & $\begin{array}{l}\text { STRENGTHS: } \\
\text { International, aristocratic } \\
\text { environment; multi- } \\
\text { culturalism, cultural } \\
\text { education } \\
\text { (conservatorium, national } \\
\text { library) } \\
\text { WEAKNESSES: small } \\
\text { creative community, small } \\
\text { student population / no } \\
\text { university; proximity to } \\
\text { Amsterdam and Rotterdam }\end{array}$ \\
\hline
\end{tabular}

All the cities considered host important events, ranging from world-known events such as the Gay Parade in Amsterdam, to runners to that status, like the Rotterdam Film Festival (one of 
the most appreciated in the world film-making community), or the North Sea Jazz Festival in The Hague. "Local" events like the Floriade in Amsterdam are by no means small, as they tend to attract every year thousands of aficionados. Some cities are especially good at programming one-off events with a large international resonance; it is the case of Rotterdam, with its European Capital of Culture 2001 only to quote a recent one. Large multicultural festivals are held in various cities of our study, among which Rotterdam with its Dunya. Small, experimental art events are coming out of an almost underground status to establish themselves as important additions to the city's cultware and image markers: the Virus Festival in Eindhoven is an example. Finally, it should be remembered that some cities can afford an ordinary programming of such quality and visibility that it could be considered an event in itself, like the musical and theatre programming in Amsterdam, and the temporary and permanent exhibitions at Amsterdam's, The Hague's and Rotterdam's museums.

Each city has a distinct cultural image. Amsterdam is seen as a city of tolerance, creativity, and participation, with high cultural standards, and one where the accent is on intangible rather than on tangible cultural assets. The Hague is a bourgeois, multicultural city hosting important national and international institutions. Eindhoven has a young, innovative business environment and has potential to become a creative technological hub. In Rotterdam, the highlight is modern architecture, multi-ethnicity, experimentation in art and culture for public spaces and cityscape. 


\section{Size of cultural sector}

Table III offers an illustration of the various information and estimates collected by the authors in the different cities. It can be stated that "traditional" cultural activities - including productions and performances in the fields of fine arts and the arts market, performing arts and entertainment, music, museums \& libraries - is a very large sector compared to the size of the local economy in Rotterdam, where it represents around $4.5 \%$ of the employment; in second rank come Amsterdam and The Hague, with cultural sectors counting around $2.5 \%$ of local employment; last comes Eindhoven, where the employment in cultural production is negligible at $0.5 \%$ of total city or regional employment. In absolute numbers, Amsterdam's cultural sector has probably the largest size with more than 19,000 workers in the sector in the urban agglomeration, followed by Rotterdam $(13,700)$.

Tab. III - Size of the cultural cluster

\begin{tabular}{|c|c|c|c|c|}
\hline & $\begin{array}{l}\text { estimated n. of jobs in } \\
\text { core cultural activity } \\
\text { sectors*; est. number of } \\
\text { producers/organisations }\end{array}$ & $\begin{array}{l}\text { estimated n. of jobs } \\
\text { in cultural and } \\
\text { creative industries, } \\
\text { est. number of } \\
\text { producers }\end{array}$ & $\begin{array}{c}\text { sectors } \\
\text { considered } \\
\text { in } \\
\text { statistics** }\end{array}$ & $\begin{array}{l}\text { estimated } \\
\text { economic } \\
\text { impact }\end{array}$ \\
\hline AMSTERDAM & $\begin{array}{c}19,190 \text { fte }(2.4 \% \text { of total } \\
\text { employment in the } \\
\text { region) in } 2002 . \text { In } 1989, \\
\text { Van Puffelen counts } 270 \\
\text { organisations in } \\
\text { performing arts, } 180 \text { in } \\
\text { the } \\
\text { distribution/exhibition } \\
\text { sector, } 81 \text { supporting and } \\
\text { intermediaries }\end{array}$ & $\begin{array}{c}32,500 \text { fte }(4 \%) \\
5,592 \text { firms }(9 \%) \\
(2002)\end{array}$ & $\begin{array}{l}\text { All creative } \\
\text { production } \\
\text { sectors } \\
\text { (sports not } \\
\text { incl.) }\end{array}$ & $\begin{array}{l}€ 650 \mathrm{~m} \\
(1994)\end{array}$ \\
\hline EINDHOVEN & $\begin{array}{c}\text { Negligible figures of } \\
\text { employment and } \\
\text { producers }\end{array}$ & $\begin{array}{l}\text { Est. } 30,000 \text { creative } \\
\text { industry workers }(8 \% \\
\text { of employment in } \\
\text { Eindhoven region); } \\
8,000 \text { firms in } \\
\text { creative production } \\
\text { sectors }(3,000\end{array}$ & $\begin{array}{l}\text { All creative } \\
\text { production } \\
\text { sectors in } \\
\text { Eindhoven } \\
\text { region, incl. } \\
\text { tourism and } \\
\text { sports }\end{array}$ & $\begin{array}{l}\text { Est. } € 1,200 \mathrm{~m} \\
\text { in Eindhoven } \\
\text { region } \\
\text { (approx. } 3 \% \\
\text { of total } \\
\text { regional } \\
\text { turnover) }\end{array}$ \\
\hline
\end{tabular}




\begin{tabular}{|c|c|c|c|c|}
\hline & & designers) & & \\
\hline ROTTERDAM & $\begin{array}{c}13,766 \mathrm{fte}(4,5 \% \text { of } \\
\text { employment }) \text { in } 2004 \text { and } \\
920 \text { firms/organisations }\end{array}$ & $\begin{array}{c}10,300 \mathrm{fte} \text { in } 2004 \\
(3.3 \%) ; 100 \\
\text { audiovisual producers } \\
\text { in } 2002 .\end{array}$ & $\begin{array}{l}\text { All creative } \\
\text { production } \\
\text { sectors } \\
\text { (tourism and } \\
\text { sports excl.) }\end{array}$ & $\begin{array}{c}\text { Est. added } \\
\text { value } \\
\text { produced in } \\
2004 € 400 \mathrm{~m} \\
(2.2 \% \text { of city } \\
\text { economy) }\end{array}$ \\
\hline THE HAGUE & $\begin{array}{c}3,172 \text { fte }(1,4 \%) \text { and } 660 \\
\text { firms in core cultural } \\
\text { production }(2,3 \% \text { of } \\
\text { total })(2002)\end{array}$ & $\begin{array}{c}13,196 \text { fte in } \\
\text { "culture, sports and } \\
\text { recreation" in } 2005 \\
(5.8 \%) ; 1,540 \text { firms in } \\
\text { other creative } \\
\text { production sectors } \\
(5.5 \%) \text { and } 2,515 \text { in } \\
\text { tourism }(8.9 \%) \text { in The } \\
\text { Hague agglomeration } \\
\text { in } 2002 \text { (unknown } \\
\text { employment) }\end{array}$ & $\begin{array}{l}\text { All creative } \\
\text { production } \\
\text { sectors incl. } \\
\text { tourism } \\
\text { (sports excl.) }\end{array}$ & Not available \\
\hline
\end{tabular}

*: Fine arts and the arts market, performing arts and entertainment, music, museums \& libraries

**: Architecture, Audiovisual, Graphic arts / fashion / design, Literature / publishing / music recording and production / print media, Software / multimedia / games / Internet

The picture changes dramatically when the creative industries are taken into account. Employment in sectors such as architecture, audiovisual, graphic arts, fashion, design, literature, publishing, music recording and production, print media, software, multimedia, games, and internet is a large sector (and a growing one) in Amsterdam, Eindhoven, and The Hague, counting for $4 \%$ to $8 \%$ of total employment (the urban agglomerations of Amsterdam getting the largest cultural industries in absolute terms, with 32,500 jobs). Rotterdam, with 10,300 jobs, has only $3.3 \%$ of its workforce employed in creative industries, less than in the "core" cultural sectors. 
Not all cities have attempted a full evaluation of the impacts of culture on the local economy, and methods to effect such evaluation may greatly differ (from total expenditure multipliers to input-output analyses and estimations of total added value). Amsterdam has tried this many times, and the most complete study conducted by KPMG ten years ago estimated in some $€ 650$ million the total impact of cultural activity in the urban region - in strong increase $(+43 \%)$ over the previous estimate doen in 1983 - and a regional added value of $€ 227 \mathrm{~m}$, roughly $1.4 \%$ of the added value of all sectors in the Amsterdam economy. Eindhoven, with an estimated $€$ 1,200 of total effects, seem to enjoy the largest impacts, but this figure regards total visitor activities in the region; the net effect of culture of the city or its agglomeration is likely to be much lower.

In the other cities only guesses might be tempted. It should be pointed out that not in all the cities the sectors or their subsectors are growing, though this is the overall trend in European regions. Some cities have seen a strong growth in the last decade, with some sectors doing better than others; in particular, filmmaking and video production have undergone severe restructuring almost everywhere as are firms dealing with software and ICT applications. In Eindhoven and The Hague, the signals are contrasting, with sectors growing but also a decreasing level of "transfer" of culture to the community. A recent report published by the Dutch Ministry of Economic Affairs confirms the difficulty that especially The Hague has found to translate its cultural resources in economic development potential. 


\section{Spatial organisation and structure of the cultural sector}

To varying degrees and in different ways, all the cities in this study present a concentration of cultural activity and firms in specific portions of the city (Table IV). In most cases, these concentrations are merely the result of the historical evolution of the urban space and of the location choices of firms.

In this respect, the inner historical cores - rich in historical marks and symbolic sites for the local identity - have emerged as the preferred location for leisure activities where "ambience" has a strong importance. Thus, Amsterdam and The Hague all have monumental city cores, mostly of medieval origin, rich in attractions and atmospheric elements, which serve as perfect "stages" for leisure and tourist activities and events. Furthermore, heritage provides status and visibility to all sorts of commercial activities.

The actors in these districts are prevailing of the "institutional type" (museums and galleries, theatres, the Church, the public administration), as well as private households maintaining old mansions and palaces, which become nonetheless part of the visitors" experience (and are, to some extent "institutionalised" through conservation and planning policy). The functional links between them are loose, to the point that the technical term of "cluster" hardly applies. Visitor demand prevails as the "economic bind" of the district, rather supply-side economies. 
Tab. IV - Spatial organisation and structure of the cultural cluster

\begin{tabular}{|c|c|c|c|c|}
\hline & $\begin{array}{c}\text { Existence of a } \\
\text { cluster or } \\
\text { different cluster } \\
\end{array}$ & Cluster model & $\begin{array}{c}\text { Role of public vs. } \\
\text { private } \\
\text { organisations }\end{array}$ & $\begin{array}{c}\text { Growth rate } \\
\text { trends of cultural } \\
\text { firms and projects }\end{array}$ \\
\hline AMSTERDAM & $\begin{array}{c}\text { Main cultural } \\
\text { clusters: Museum } \\
\text { quarter (museums, } \\
\text { galleries, classical } \\
\text { music); Jordaan } \\
\text { (café culture, art } \\
\text { trade); Oud West } \\
\text { (ateliers, } \\
\text { visual/plastic arts); } \\
\text { Westergasfrabriek } \\
\text { (art, media, } \\
\text { events); Oost } \\
\text { (architecture); } \\
\text { Media cluster } \\
\text { (North bank of Ij } \\
\text { river); broadcast } \\
\text { cluster in } \\
\text { Hilversum }\end{array}$ & $\begin{array}{c}\text { Many different } \\
\text { ones. } \\
\text { Westergasfabriek, } \\
\text { Oud West: peer } \\
\text { producers, strong } \\
\text { internal } \\
\text { governance. } \\
\text { Division between } \\
\text { fine and pop arts, } \\
\text { lack of shared } \\
\text { platforms. }\end{array}$ & $\begin{array}{l}\text { Local government } \\
\text { support clustering } \\
\text { and cooperates } \\
\text { with cluster } \\
\text { members. Cluster } \\
\text { dominated by } \\
\text { private and non- } \\
\text { profit firms. }\end{array}$ & $\begin{array}{l}\text { Growing workforce } \\
\text { in the arts and } \\
\text { creative industries. } \\
\text { New development } \\
\text { of cultural spaces } \\
\text { and infrastructure: } \\
\text { media cluster, art } \\
\text { park at the } \\
\text { Westerstraat, } \\
\text { former shipyard } \\
\text { site of NDSM, } \\
\text { Danshuis } \\
\text { Amsterdam at } \\
\text { Oostergasfabriek. }\end{array}$ \\
\hline EINDH & $\begin{array}{c}\text { Aggregation of } \\
\text { cultural facilities } \\
\text { in city centre; } \\
\text { Strijp S, } \\
\text { Dommelzone, } \\
\text { Westcorridor as } \\
\text { potential new } \\
\text { potential creative } \\
\text { clusters }\end{array}$ & $\begin{array}{c}\text { Institutional } \\
\text { network (museums, } \\
\text { podia) with no } \\
\text { recognised leader } \\
\text { in creative } \\
\text { production sector } \\
\text { but large "clients" } \\
\text { (Philips, TU/E) }\end{array}$ & $\begin{array}{c}\text { Strong public } \\
\text { leadership, and } \\
\text { potential private } \\
\text { networkers (Alice, } \\
\text { MU, Stichting } \\
\text { City Dynamiek } \\
\text { Eindhoven, Trudo) }\end{array}$ & $\begin{array}{l}\text { Increasing number } \\
\text { of planning and } \\
\text { economic } \\
\text { development } \\
\text { activities involving } \\
\text { creative production } \\
\text { sectors }\end{array}$ \\
\hline ROTTERDAM & $\begin{array}{l}\text { Visual/ plastic art, } \\
\text { art market and café } \\
\text { culture cluster in } \\
\text { Museumpark/ } \\
\text { Witte-de- } \\
\text { Withstraat. } \\
\text { Cultural incubators } \\
\text { in peripheral } \\
\text { regenerated } \\
\text { industrial estates. } \\
\text { Cultural cluster on } \\
\text { the south bank of } \\
\text { the Maas river } \\
\text { (theatre- } \\
\text { exhibitions- } \\
\text { restaurants- } \\
\text { heritage). Heritage } \\
\text { cluster in } \\
\text { Delftshaven. } \\
\end{array}$ & $\begin{array}{c}\text { Film festival, } \\
\text { Boymans museums } \\
\text { and De Doelen } \\
\text { dominating actors } \\
\text { in culturalsphere. } \\
\text { Peer relations } \\
\text { between small } \\
\text { creative } \\
\text { businesses. No } \\
\text { sharp divisions } \\
\text { among genres / } \\
\text { markets. }\end{array}$ & $\begin{array}{l}\text { Central role of } \\
\text { public sector } \\
\text { (national and } \\
\text { local) and public } \\
\text { initiative in } \\
\text { clustering. } \\
\text { Follower } \\
\text { behaviour of small } \\
\text { creative } \\
\text { businesses. } \\
\text { Conflicts arising } \\
\text { with ethnic } \\
\text { communities. }\end{array}$ & $\begin{array}{l}\text { Stable to declining } \\
\text { employment in } \\
\text { creative industries, } \\
\text { growing } \\
\text { employment in } \\
\text { traditional cultural } \\
\text { production. Growth } \\
\text { potential in the } \\
\text { media industry. }\end{array}$ \\
\hline THE H & $\begin{array}{l}\text { Aggregation of } \\
\text { cultural producers } \\
\text { and events in city } \\
\text { centre (Spuiplein) }\end{array}$ & $\begin{array}{l}\text { Museum / } \\
\text { performing arts } \\
\text { "institutional" } \\
\text { cluster }\end{array}$ & $\begin{array}{l}\text { Dominance of } \\
\text { public actors }\end{array}$ & $\begin{array}{c}\text { Broadcasting } \\
\text { among "growth } \\
\text { industries" }(+25 \% \\
\text { in } 95-01) ; \\
\text { declining number }\end{array}$ \\
\hline
\end{tabular}


Culture-oriented businesses, like art galleries and markets, fashion shops, music venues, cafés and clubs, bookshops, as well as other typical visitor facilities like restaurants and hotels, find in heritage districts an ideal setting for their activity. The "inspiration" that they may derive from the ambience is an important factor of location for them, but the fact that in this way they come in close contact with a culturemotivated (and willing to pay) demand is certainly prevailing. Even in cases when contact with the final demand is not so important, like in the case of graphic designers, ateliers and film studios, the "clustering" element - the knowledge flows and the contact with peer producers and consumer firms - may explain the preference of these industries to be located in city centres. However, in most "mature" inner city clusters (Amsterdam), agglomeration diseconomies are now on the rise. For some years now, creative firms, often small and lacking structure as businesses, have been flowing out of the old inner cities to less central neighbourhoods in search of low rents and a more "genuine", dynamic urban setting. This move often led the way in the creation of new urban centralities, as happened in the 1970s in Amsterdam's Oud West. To some extent, also Rotterdam, a city which in the last decades had pointed decidedly to the contemporary elements in its cultural planning policy, is now rediscovering its old historical quarters, the central Witte-de-With and the slightly more off-centre Oud Noord and Delfshaven, inspiring "heritage clusters" for cultural activity.

Inner-city heritage districts, however, are not the only models of cultural agglomeration. Other types of cultural or creative 
agglomeration are not so much connected to a "setting" and only loosely founded on institutional powers, rather, they are driven by supply-side economies and informal value-sharing within a group of leading actors or trendsetters, creating their own institutions or rules, and selecting locations on the basis of costs and convenience for their particular area of operation. In these cases, the role of the public authority may vary from being the starting actor that "empowers" cultural entrepreneurs and allocates property rights, maintaining the control on its evolution and orientation (it is the case of Rotterdam's Wittede-With and Lloydqwartier clusters), to just being a facilitator of the process of clustering and one of the actors in its governance (like in the cases of the Westergasfabriek complex and of the new media cluster in Amsterdam).

Finally, we identify a new type of cluster in which the creative activity regards closely the interaction of culture and technology. Eindhoven seems to be leading the way in this respect with one large university cluster and more coming up, including the new Philips science park. Amsterdam is following the same path with its new media cluster. In these cases, of course, universities and research centres are key actors. Yet, they need to build solid links with the business community, especially the small and medium firms and (often start-ups of their own alumni), something which only a surprisingly limited number of institutes are equipped to do; and they need to take in full consideration the "living climate" of the student and workers' community, again a neglected question which is becoming a real challenge for cities (Van den Berg and Russo, 2004).

The different models and organisation structures have had a wide range of outcomes, and it is very hard to establish neat 
causal links between the "planning model" underlying the development of a specific cluster and their performance after some years, or to evaluate the level of that performance. The only valuation can be based on the aspirations of the stakeholders; thus, Amsterdam is a city which has achieved probably much more than what was expected in the first place from cultural clustering, from the "spontaneous" transformations of various city centre areas in the 1960 s to the most recent "open planning" approach of the next decades, where there has been strong confidence in the self-organising capacity and in the ecology of the sector. The cultural clusters of Amsterdam have been the backbone of its creative industry development, which has generated many valuable jobs and development opportunities for some of the weaker parts of the local society; for instance, modern dance, a typical "urban culture" movement largely appealing to ethnic minorities and cultivated in squatted houses and theatres in peripheral neighbourhoods, has been estimated to be a sector worth $€ 5 \mathrm{M}$ of turnover, and 11,000 jobs in the country.

Rotterdam and The Hague, by comparison, have achieved less than what they expected. Rotterdam by insisting on "hard planning" of creative clusters and not working with sufficient intensity on the "cultural conditions" which give life to a creative industry; and The Hague by focusing much more on "consumption" and "atmospheric" elements of cultural clustering at the expenses of the development of working links between the participants of the cluster and with the local institutions. Eindhoven seems to be looking at an altogether different model, possibly that of Manchester, where popular cultural is coming in contact with the tech-end of the local economy, and the challenge for creative entrepreneurs is to become embedded and valuable to that economic model. 


\section{Integration with the urban economy}

The key aspects of the relationship between cultural activities and the wider urban economy of the ten case studies are addressed and illustrated in Table $V$. The main idea of the COED model is that culture has durable and significant economic effects as long as it manages to pervade any aspect of the "way of doing" of the city, in the sense of enhanced innovativeness, creativity and flexibility.

Most cities included in our study do have the resources to escape the "mass tourist" cliché and to continuously reformulate their cultural image, mixing tradition and innovation and thus remaining attractive to new waves of culture-motivated travellers. This is what Amsterdam is doing, attracting 6 millions of visitors every year to its cultural attractions.

The Hague, Eindhoven, Rotterdam, have just the right size of cultural tourism according to their mass of attractions and their level of accessibility, and manage to attract huge crowds only in specific circumstances when large events are organised. Lacking real "selling points", their cultural clusters do not represent particular points of attraction to visitors, with the possible exception of the filmmaking industry of Rotterdam and its world-known cinema festival. Eindhoven and its techart can't expect to attract huge crowds but offer a pleasant diversion to the more than 12 million visitors of the surrounding regions and to its university students; The Hague, a city at a short distance from almost anywhere else in the Netherlands, is trying to bring itself to be the "music capital" of the country. 
Aside from tourism, culture and creativity may also be expected to stimulate the local residents and enhance their quality of life. Especially Amsterdam is perceived as the only real national hotspot for a wide range of professions at the edge between creativity, personal services, finance and technology, and has been one of the most appealing cities to live in for foreigners from inside and outside Europe for decades. In fact, participation to the Amsterdam job market rose from $63 \%$ to $69 \%$ in the period $1994-1999$, with $40 \%$ of the newest jobs taken by non-nationals. Many job positions have been moving into Amsterdam from the rest of the country, and especially from the Rotterdam region. In total, jobs have risen from 300,000 to almost 400,000 in the last 35 years. This growth was accompanied by a policy of making available new land and buildings for housing and businesses, as well as by new developments in the social and cultural provision of the city for its shifting social mix. Today, Amsterdam is especially attractive for creative talents and artists, who enjoy the generous support deployed by the city to contribute to a culturally stimulating, challenging and socially balanced city both in the city centre and in peripheral neighbourhoods, something that turns out to be an important location factor for new business professionals. Apart from the sectors which naturally thrive in a creative environment, among which the media, entertainment, music recording, software, architecture and telecom industries are Amsterdam's strongest, also banks, insurance companies and international law firms appreciate the peculiar living climate of the Dutch capital. 
Tab. V - Integration of culture with the urban economy

\begin{tabular}{|c|c|c|c|c|}
\hline & $\begin{array}{c}\text { Size of cultural } \\
\text { tourism }\end{array}$ & $\begin{array}{l}\text { Quality of life } \\
\text { effects from } \\
\text { culture }\end{array}$ & $\begin{array}{l}\text { Growth clusters } \\
\text { in local economy } \\
\text { affected by a } \\
\text { creative } \\
\text { environment }\end{array}$ & $\begin{array}{c}\text { Level of } \\
\text { corporate } \\
\text { support }\end{array}$ \\
\hline AMSTERDAM & $\begin{array}{c}1 / 4 \text { of visitors } \\
(1.5 \mathrm{~m} \text { foreigners) } \\
\text { motivated by arts } \\
\text { in } 1980 \mathrm{~s} \text { (Van } \\
\text { Puffelen), } \\
\text { contributing } € \\
200 \mathrm{~m} .13 .6 \mathrm{~m} \\
\text { visits to main } \\
\text { cultural } \\
\text { attractions in } \\
2002 .\end{array}$ & $\begin{array}{c}\text { Wide supply of } \\
\text { cultural events for } \\
\text { local population; } \\
\text { tolerant } \\
\text { atmosphere; } \\
\text { bustling street life } \\
\text { in shopping } \\
\text { centre, quiet, } \\
\text { aristocratic } \\
\text { central } \\
\text { neighbourhoods. }\end{array}$ & $\begin{array}{l}\text { Hi-tech and ICT, } \\
\text { multimedia, } \\
\text { audiovisual } \\
\text { production and } \\
\text { design. Bank and } \\
\text { insurance sectors } \\
\text { enjoy optimal } \\
\text { living conditions } \\
\text { for staff. }\end{array}$ & $\begin{array}{c}\text { High: private } \\
\text { sector investments } \\
\text { in new } \\
\text { audiovisual/media } \\
\text { projects, art } \\
\text { collections, } \\
\text { rehabilitation of } \\
\text { buildings for } \\
\text { cultural uses }\end{array}$ \\
\hline EINDHOVEN & $\begin{array}{l}2.8 \mathrm{~m} \text { visits to } \\
\text { cultural } \\
\text { attractions, } \\
650,000 \\
\text { attendants to } \\
\text { events }\end{array}$ & $\begin{array}{c}\text { Cosy city centre, } \\
\text { attractive } \\
\text { environment for } \\
\text { incoming } \\
\text { professionals }\end{array}$ & $\begin{array}{c}\text { Engineering, } \\
\text { design, gaming, } \\
\text { ICT }\end{array}$ & Low \\
\hline ROTTERDAM & $\begin{array}{c}\text { Cultural tourism } \\
\text { boosted by } 2001 \\
\text { ECC event }(2.2 \mathrm{~m} \\
\text { visitors came on } \\
\text { purpose) but } \\
\text { presumably } \\
\text { decreased since } \\
\text { then. Most visited } \\
\text { tourist attractions } \\
\text { are not strictly } \\
\text { cultural: Zoo, } \\
\text { Casino, Spido, } \\
\text { Tropicana. }\end{array}$ & $\begin{array}{c}\text { Investments in } \\
\text { cultural events } \\
\text { achieved a certain } \\
\text { level of social } \\
\text { integration and } \\
\text { revitalisation of } \\
\text { deprived areas. } \\
\text { WdW contributed } \\
\text { to the animation } \\
\text { of city centre, but } \\
\text { effects from } \\
\text { cultural activity } \\
\text { are below } \\
\text { potential. }\end{array}$ & $\begin{array}{l}\text { Audiovisual, } \\
\text { architecture and } \\
\text { design, music } \\
\text { production. }\end{array}$ & $\begin{array}{c}\text { Below standards. } \\
\text { Fair inflow of } \\
\text { private capital in } \\
\text { Lloyds quarter } \\
\text { development }\end{array}$ \\
\hline THE HAGUE & $\begin{array}{l}1,2 \mathrm{~m} \text { attendants } \\
\text { to events; } 0,8 \mathrm{~m} \\
\text { visitors to major } \\
\text { museums }\end{array}$ & $\begin{array}{c}\text { Fair supply of } \\
\text { cultural events } \\
\text { and facilities. } \\
\text { Negligible image } \\
\text { effects from } \\
\text { creative } \\
\text { production }\end{array}$ & $\begin{array}{c}\text { Tourism, ICT, } \\
\text { media }\end{array}$ & Low \\
\hline
\end{tabular}

The Hague is a city of prestige that is now thinking to invest in its music scene to be more popular with the young and skilful, but competes with consolidated entertainment hubs at close range, like Amsterdam and Rotterdam. Eindhoven and 
Rotterdam are examples of cities in which culture, in spite of its recent developments, has not yet made a big impact in quality of life and residential or business choices. Rotterdam is possibly the "dream city" for architects and is a pleasant (and relatively cheap) living location for any other professional, but it is a city with a suburbanised middle class, where culture has always been intended more as a factor of social inclusion (without achieving all that was promised) than a lever for regeneration and gentrification. Cultural participation is low, even in occasion of large events as the European Cultural Capital year in 2001, and especially visitors feel not always feel safe in the city centre. Today the policy agenda has shifted, but a new cultural strategy has not followed suit, and Rotterdam runs the risk of being perceived as a parochial, culturally lagging city compared to the potential that it has. Eindhoven is still struggling to be attractive to anybody, and invests a lot of ideas and money in the process of upgrading its cultural infrastructure, its living climate and recreational opportunities, but for the moment it continues to be perceived as a big village for tech-heads and peaceful households, more appreciated for its natural surroundings than for its urban climate. Design, though, has the potential to become the "export" knowledge industry of Eindhoven, at the same time attracting investments and talent in the area, as is demonstrated by the recent interest that this local specialisation and its educational apparatus raised in the international press.

In some of our cities we have noted a more proactive, aware role of the business community towards cultural development. Notably, in Amsterdam the private sector is convinced of the importance of "seed-funding" creativity investing in people, places, and projects. A real best practice may be quoted, that of an important corporation in real-estate and transport, which 
supports squatting projects with the idea of enhancing "spaces of creativity" in the city and stimulating a positive evolution in the local society. This far-fetching attitude is limited to a few examples but it might have profound impacts in the long term. In other cities, business communities are less at hand with the notion of sustaining a creative environment; this is the case of Rotterdam, where the economic history is not tied to creativity, and the (necessary) move to a more free-form development of the knowledge economy is looked at with some reluctance. Presently - under the lead of the local economic development agency - Rotterdam's private companies are investing in the Lloydsquartier, the new media cluster of the city, but they are not oriented to put money in "soft" place qualities, which would give real life and perspective to the cluster: education, housing, public space.

In The Hague, culture and art are traditionally believed to be part of the public realm and attract generous support, thus making corporate involvement not strictly necessary if not a softer level as a way to make culture "expendable" in economic development, a concept which still meets string resistances in the local society, as revealed by the scepticism with which new projects linking more closely creativity with business are regarded.

\section{Sustainable development of the cluster}

In this section, we turn to look at three important levels of "consistency" in urban development, which are necessary forth long-term sustainable outcome of the COED process. The main elements are described in Table VI. 
Almost all the cities investigated have, more or less intentionally, tied their cultural activity patterns to specific locations. if area renewal is what is looked for, and no "hard" controls are enforced on land uses, prices and "character", gentrification and "sanitisation" of the areas may easily set in. In a way, this could be considered a measure of the success of the regeneration strategy, but the spatial-economic characteristics which are at the basis of the cultural cluster low barriers to entry, proximity and networking among producers, and mixedness of living, consumption and consumption spaces - could come less.

At that point, cultural development could be considered just an accessory stage of area renewal, "migrating" from one zone to the city to the other in a cyclic pattern of urban development, often "spiralling" away at further and further distances from the city centre. There is continuity between spatial consistency and the concern for the maintenance of a social mix in an area or city. The four case studies show that at a certain stage of evolution of cultural economies, social issues have emerged and have been taken in consideration both by city planners and the public sector at large, and by the members of the creative business community.

A minimum level of social equity in the COED model is guaranteed by democratisation of access to culture. The valuation of culture can lead to the formation of private markets and an increase in access costs; this could eventually result in a lower participation in cultural activity by disadvantaged groups. "Inclusion" issues regard mainly the use of cultural programmes to influence the behaviour, participation and discourse of disadvantaged groups and minorities. In Amsterdam they have been at the centre of 
cultural development programmes of the education department, aiming at effective multicultural integration, but also in corporate strategies where a number of private cultural producers and music clubs have joined forces to bring cultural activities and develop infrastructure in disadvantaged neighbourhood in the periphery. Amsterdam's Kunstenplan (a four-year funding scheme for cultural activity) is a good example of cultural policy agenda that does not stop at the boundaries of art and culture but has the ambitions to become levers for generalised urban development.

Tab. VI - Sustainable development of the cluster

\begin{tabular}{|c|c|c|c|}
\hline & Spatial-economic balance & $\begin{array}{l}\text { Social concern (access, } \\
\text { inclusion, openness, } \\
\text { diversity) }\end{array}$ & Cultural identity \\
\hline AMSTERDAM & $\begin{array}{l}\text { Large culture-driven } \\
\text { regeneration effects in } \\
\text { West (Westergasfabriek, } \\
\text { Jordaan), Old West, East } \\
\text { and waterfront, more } \\
\text { recently northern bank of } \\
\text { river Ij. }\end{array}$ & $\begin{array}{l}\text { Art and culture explicitly } \\
\text { utilised as strategy for } \\
\text { inclusion by public (DMO) } \\
\text { and private (Cosmic, } \\
\text { Paradiso, etc.) actors }\end{array}$ & $\begin{array}{l}\text { Lively debate on } \\
\text { development of a "creative } \\
\text { city strategy". Problems } \\
\text { with preservation of points } \\
\text { of attractiveness for } \\
\text { creative talents: low entry } \\
\text { barriers, concentration of } \\
\text { living / working space, } \\
\text { accessible city centre }\end{array}$ \\
\hline EINDHOVEN & $\begin{array}{l}\text { Culture and creativity as } \\
\text { spearheads of economic } \\
\text { regeneration / } \\
\text { diversification. } \\
\text { Regeneration potential in } \\
\text { Strijp S }\end{array}$ & $\begin{array}{c}\text { Insufficient attention to } \\
\text { social inclusion in cultural } \\
\text { investment and } \\
\text { programming; fair level of } \\
\text { integration of student } \\
\text { community through virtual } \\
\text { networking and e- } \\
\text { government }\end{array}$ & $\begin{array}{l}\text { High relevance of culture } \\
\text { for economic development } \\
\text { and focus on creative } \\
\text { combinations }\end{array}$ \\
\hline ROTTERDAM & $\begin{array}{c}\text { Regeneration of central } \\
\text { areas and waterfront } \\
\text { achieved through cultural } \\
\text { investment and location } \\
\text { policies (WdW) and } \\
\text { flasghip architecture } \\
\text { (KvZ). Other landmark } \\
\text { regeneration projects in } \\
\text { peripheral industrial areas } \\
\text { (Van Nelle, Schiecentrale). }\end{array}$ & $\begin{array}{l}\text { Multi-cultural city image } \\
\text { now at the centre of } \\
\text { debate. Scarce capacity of } \\
\text { the city to attract and } \\
\text { retain creative talent. }\end{array}$ & $\begin{array}{c}\text { Excessive multiculturalism } \\
\text { now seen as a problem } \\
\text { (and expensive), poor } \\
\text { results of cultural policy } \\
\text { require change in } \\
\text { approach. }\end{array}$ \\
\hline THE HAGUE & Culture-themed & Wide and mixed & Low levels of cultural \\
\hline
\end{tabular}




\begin{tabular}{|c|c|c|c|}
\hline $\begin{array}{c}\text { Centre cultural axis and } \\
\text { City Mondial }\end{array}$ & $\begin{array}{c}\text { participation in cultural } \\
\text { events; culture used for } \\
\text { integration in new strategy } \\
\text { document }\end{array}$ & $\begin{array}{c}\text { investment, insufficient } \\
\text { cultural branding of the } \\
\text { city }\end{array}$ \\
\hline
\end{tabular}

In Rotterdam, a city with a large migrant population (more than $60 \%$ of the under- 18 are non-white, more than $40 \%$ of the population is of allocthonous origin) inclusion has been for long at the centre of cultural policy and even urban planning: social housing has been carefully located in central areas, and urban public space has been realise so as to provide occasions for meeting between communities and cultural expression. The celebrations of eccentric cultures like the Caribbean, the Surinamese, the Turkish, and all the other 103 nationalities hosted in this unique city - the festivals, the restaurants, the musical programming, the urban youth cultures - managed to create a "melting pot" atmosphere which may have few other equals in Europe and results attractive to both the occasional visitor and the more experienced cultural tourist. A novel program seeks to develop "non-white" areas as cultural districts and to bring civics and mutual discover in primary school education. In Eindhoven, the city of technical innovation, cultural integration is sought for through the creation of virtual communities, an integral part of the Kenniswijk project (knowledge-quarter). The idea is that through e-government and seamless information circulation, different cultural codes (by students, local residents, foreign workers) can be bridged, resulting in amore cohesive society, and these groups can be served more effectively by the local government.

Another concern regarding the social balance in the COED model for a city regards its openness and attractiveness for new groups that may enrich and integrate, possibly without 
substituting, the local human capital. In a few cases, these concerns touch the cultural field. Amsterdam has the best program (richly founded by the local government) to host artists and give them working space to produce works of art and generate a "cultural climate" in the city.

Finally, cities should not forget their cultural identity in an attempt to change the pace of their economy and socioeconomic trends. Changing by adaptation, rather than negating their history should be the key concern, even when the latter is contested. British cities are perfect illustrations of an almost forgotten cultural heritage of industrial splendour that has been re-vamped as a "setting" for cultural and creative industries. The industrial past is also the dominating cultural theme in Eindhoven, which is re-valuing its visible signs and its legacy of knowledge and community spirit. Rotterdam may be a best practice of valorisation of the special relation that there exist between a city and its community and the sea. Maritime splendour also evokes concepts of dynamism and openness, which Rotterdam has shown to capture in its eye-catching architectural development and its multicultural flavour.

The Hague is a city of noble origins and aspect, the seat of national governments and of the merchant elites of the Netherlands; this is reflected in its cultural provision, never too hot for the "new" in spite of consolidated artistic celebrations like the North Sea Jazz festival. However competition, both national and foreign, is today strong in fields like cultural industries and the knowledge economy; the need is felt to open up the local environment to creative forces. This means re-discussing radically the axis of the local cultural policy and creating new networks supporting the rise of "new" 
creative activities possibly on the shoulders of the traditional ones.

\section{CONCLUSIONS}

This study set out to propose a theoretical framework to interpret and possibly steer culture-oriented urban development: the COED model.

The comparative analysis of the four cities confirms some of the intuitions of the COED model. In cities where a certain number of "cultural clusters" have emerged, the urban economy has been structurally modified towards the symbolic. Cultural clusters have become - to varying extents, according to the characteristics, location and governance structures of such clusters - catalysts of a wholesome creative economy, involving a higher attractiveness for tourists, skilled talents, and ultimately for knowledge-intensive enterprises in search of an innovative climate and high levels of quality of life.

However, culture-oriented economic development is subject to strong endogeneity, modifying continuously the original conditions that make places culturally rich and viable as creative hubs. COED is potentially short-lived and may bring to irreversible changes in the urban environment: the erosion of social capital, the dispersion in space of cultural activities and the consequent decreasing of clustering effects, and ultimately the fading of local cultural identity and "uniqueness". Urban policy should be careful to accompany the COED process making sure that these limits are never reached. Physical and cultural planning, social and educational policies, infrastructure projects and the implementation of innovative 
forms of governance and networking may achieve these objectives, but the policy context is made fuzzier and more complex by the unconventional nature of economic and social processes underlying cultural activities and creative production. The development of a cultural industry may follow fast cyclic patterns and be "erratic" in space, but as long as creative talents are attracted to the city, and the spatialeconomic conditions (possibly supported by targeted area policies or entrepreneurial support) allow the sedimentation of a critical mass of organisations and businesses characterised by the typical traits of the "cluster economy", cultural production will emerge and stay as a driver for urban economic development.

The four cities have been assessed and benchmarked against the development of this model. We find that some cities have progressed more than others to develop their cultural sectors into full catalysts for economic growth, in the case of Amsterdam the limits which would modify the conditions for sustainable development are close: gentrification and changes in social mix, loss of spatial centrality in creative production sectors, lack of alternative development locations, erosion of cultural identity and character. In the other cities (Rotterdam, Eindhoven, The Hague), COED is limited to internal growth of a limited number of cultural sectors and clusters, missing to affect substantially the development opportunities for other economic sectors by influencing their innovativeness and location potentials.

A number of policy recommendations for a sustained COED leading to increased urban competitiveness as well as plenty of illustrations from best practices and common mistakes are given. Funding schemes for cultural activity were taken into 
consideration as well as programs of social inclusion through cultural education, cultural infrastructure policy, and innovative governance models, looking at interesting initiatives taken in the four cities in our study.

\section{REFERENCES}

Berg, L. van den (1987), Urban Systems in a Dynamic Society. Gower, Aldershot.

Berg, L. van den, and A. P. Russo (2004), The Student City: Strategic Planning for Students' Communities in EU Cities. Ashgate, Aldershot. Forthcoming.

Castells, M. (1996). The information age: Economy, society and culture. Volume I: The rise of the network society. Blackwell, Oxford, UK.

Eisinger, P. (2000), "The Politics of Bread and Circuses: Building the City for the Visitor Class", Urban Affairs Review 35(3): 316-333.

European Commission (1998), Culture, the Cultural Industries and Employment, Commission Staff Working Paper.

Florida R. (2002), The rise of the creative class: and how it's transforming work, leisure, community and everyday life. Basic books, New York.

MKW GmbH (2001), Exploitation and development of the job potential in the cultural sector in the age of digitalisation. Final Report - Summary. On-line document, 
http://europa.eu.int/comm/employment_social/news/2001/jul/su mmary.pdf.

Ohmae, K (1995), The End of the Nation State and the Rise of Regional Economies. Free Press, New York.

Raspe, O., and Segeren, A. (2004), "Cultural industries' binnen de Nederlandse Agglomeraties". Ruimtelijk Planbureau, The Hague.

Richards, G. \& Wilson, J.C. (2004) The Impact of Cultural Events on City Cultural Capital of Europe 2001. Urban studies 41(10): 1931-1951.

Scott, A.J., (2000) The Cultural Economy of Cities, Sage Publications, London. 